\title{
BIOSTRATIGRAPHY OF BAGHAMSHAH FORMATION BASED ON CALCAREOUS NANNOFOSSILS IN THE SOUTHWEST TABAS, IRAN
}

\author{
AZADEH BORDBAR (1) \\ $\mathrm{Ph} . \mathrm{D}$. Student in Stratigraphy and Paleontology, Department of Geology, \\ Ferdowsi University of Mashhad, Mashhad, Iran. \\ azadeh.bordbar1277@gmail.com \\ FATEMEH HADAVI (D, ABBAS GHADERI (D) \\ Department of Geology, Faculty of Science, Ferdowsi University of Mashhad, Mashhad, Iran. \\ fhadavi@ferdowsi.um.ac.ir,aghaderi@um.ac.ir \\ MARZIYEH NOTGHI MOGHADDAM (1) \\ Department of Geology, Payame Noor University, Tehran, Iran. \\ m.n.moghaddam@gmail.com
}

\begin{abstract}
The Tabas Block is part of the Central Iran microcontinent, located between the Lut Block in the East and the Yazd Block in the West. The Baghamshah Formation is the second lithostratigraphic unit from the sedimentary cycle of the Magu Group and the Baghamshah Subgroup in the Jurassic of Tabas Block. This formation is conformably underlaid with the grey pisoidal limestones of the Parvadeh Formation and overlaid with the Pectinid limestones of the Kamar-e-Mehdi Formation (Esfandiar Subgroup). In this research, the biostratigraphy of the Baghamshah Formation in the Rizu and Kamar-e-Mehdi sections, based on calcareous nannofossils, is examined. The thickness of the Baghamshah Formation in the Rizu section is $270 \mathrm{~m}$ (mostly including marl and green shales with intercalation of limestones and calcareous sandstones), and in the Kamar-e- Mehdi section is $236 \mathrm{~m}$ (composed of gypsiferous marly shales, marl, marly shales and alternation of marlshale with limestones and calcareous sandstones). According to the taxonomic studies in the Rizu section, 52 species belong to 24 genera, and in the Kamar-e-Mehdi section, 45 species belong to 23 genera of calcareous nannofossils. Based on index calcareous nannofossils, the $\mathrm{CC} 1, \mathrm{CC} 2, \mathrm{CC} 3$, and CC4 biozones established by Sissinghh in both sections were determined. It is mentioned that CC5 biozone only occur in Kamar-e-Mehdi section. According to the identified biozones, the suggested age of the Baghamshah Formation is early Berriasian-early Hauterivian in the Rizu section, and early Berriasian-late Hauterivian in the Kamar-e-Mehdi section.
\end{abstract}

Keywords: biostratigraphy, Baghamshah, calcareous nannofossils, Tabas, Iran.

RESUMO - O Bloco Tabas faz parte do microcontinente do Irã Central, localizado entre o Bloco Lut a leste e o Bloco Yazd a oeste. A Formação Baghamshah é a segunda unidade litoestratigráfica do ciclo sedimentar do Grupo Magu e Subgrupo Baghamshah no Jurássico do Bloco Tabas. Esta formação é conformavelmente subjacente com calcário pisoidal cinza da Formação Parvadeh e sobrejacente ao calcário pectinídeo da Formação Kamar-e-Mehdi (Subgrupo Esfandiar). No presente trabalho é investigado a bioestratigrafia da Formação Baghamshah nas seções Rizu e Kamar-e-Mehdi baseada em nanofósseis calcários. A espessura da Formação Baghamshah na seção Rizu é 270 m (principalmente incluindo marga e folhelho verde com intercalação de calcário e arenito calcário) e na seção Kamar-e-Mehdi é 236 m (composto de xisto margoso gipsífero, folhelho, folhelho margoso e folhelho margoso alternado com calcário e arenito calcário intercalados). De acordo com os estudos taxonômicos, na seção Rizu 52 espécies pertencem a 24 gêneros e na seção Kamar-e-Mehdi, 45 espécies pertencem a 23 gêneros de nanofósseis calcáreos. Baseado no índice de nanofósseis calcáreos, as biozonas CC1, CC2, CC3 e CC4 de Sissingh foram determinadas em ambas as seções. É mencionado que a biozona CC5 somente ocorre na seção Kamar-e-Mehdi. De acordo com a biozonas identificadas, para a Formação Baghamshah é sugerida a idade Eoberriasiana-Eo-hauteriviana na seção Rizu e Eoberriasiana-Neo-hauteriviana na seção Kamar-e-Mehdi.

Palavras-chave: bioestratigrafia, Baghamshah, nanofósseis calcários, Tabas, Irã. 


\section{INTRODUCTION}

Central Iran occupies a key position for unravelling the post-Eo-Cimmerian Mesozoic (Jurassic-Cretaceous) history of the Iran Plate. From the numerous structural units of central Iran, the Tabas Block of east-central Iran shows the thickest, most complete, and best-exposed sequence of Jurassic rocks of the region, which are crucial for the understanding of the Mesozoic evolution of the Iran Plate (Wilmsen et al., 2009). The Tabas Block is located between the Lut Block in the east and Yazd Block in the west of Central Iran. The Baghamshah Formation is the second lithostratigraphic unit from the sedimentary cycle of Magu group and Baghamshah Subgroup in the Jurassic of this block, which for the first time is here investigated for an age determination based on calcareous nannofossils.

\section{Geological setting and geographical position}

In Central Iran, the history of Jurassic sedimentary basins was largely shaped by differential subsidence and rotational movements among three blocks, called Lut, Tabas, and Yazd. These blocks are part of the Cimmerian microplate assemblage that collided with the Eurasian (Turan) Plate towards the end of the Triassic (Sengör, 1990). During the Jurassic, the Tabas Block was covered by the sea for most of the time and sediments accumulated in a basin that experienced high subsidence rates, varying both in time and space. As a result, the facies pattern is complex and may change drastically, especially at the boundaries of the block (Figure 1).

On the Tabas Block, the Magu Group, as defined by Aghanabati (1977), comprises all the Jurassic formations of the inter-regional tectonic unconformity caused by the Mid-Cimmerian tectonic phase, which according to Seyed-

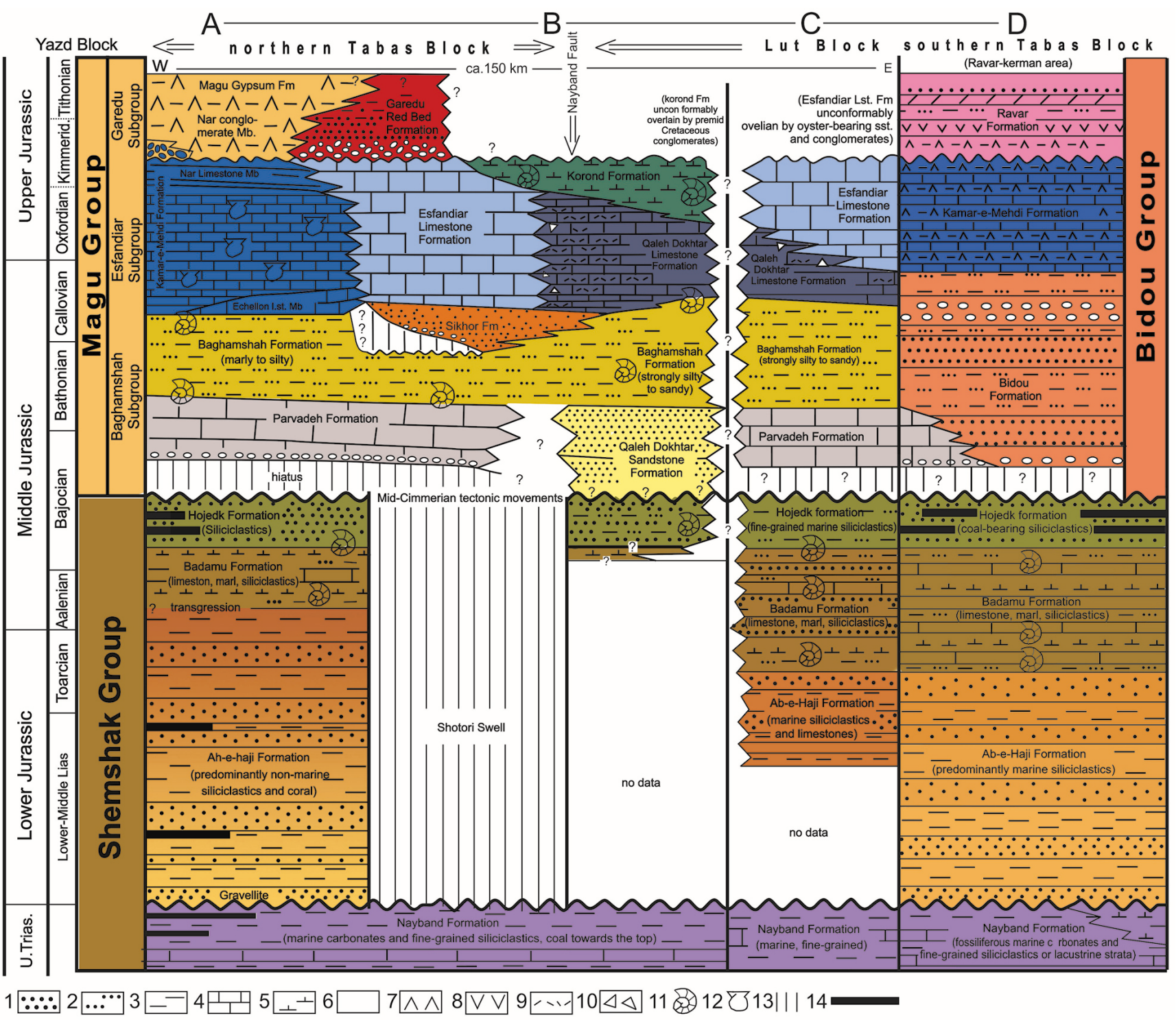

Figure 1. Lithostratigraphy of the Jurassic of the northern and southern Tabas Block, as well as the western Lut Block, east-central Iran (Wilmsen et al., 2009). The key shows the predominant lithologies and characteristic faunal elements of the formations: 1, sandstone; $\mathbf{2}$, siltstone; 3, clay; 4, limestone; 5, marl; $\mathbf{6}$, conglomerate; 7, gypsum; 8, volcanic; 9, bioclasts; 10, platform debris; 11, ammonite data; 12, bivalves; 13, hiatus; 14, coal. 
Emami \& Alavi-Naini (1990), is "mid-Bajocian" in eastcentral Iran. According to Wilmsen et al. (2009), the Magu Group subdivides into three subgroups of genetically related formations: Baghamshah Subgroup, Esfandiar Subgroup and Garedu Subgroup. These subgroups are defined based on regional boundaries that reflect subordinate tectonic events associated with major turnovers in the sedimentary regime (from predominantly siliciclastic to carbonatic deposition) (Figure 1). The Baghamshah Formation is part of the Baghamshah Subgroup, which, in the studied sections, is conformably underlying with the grey pisoidal limestones of the Parvadeh Formation and overlying the Pectinid limestones of the Kamar-e-Mehdi Formation.

Calcareous nannofossils play a strategical role in biostratigraphic studies. Thus, in this research, the biostratigraphy of the Baghamshah Formation in Rizu and Kamar-e-Mehdi sections was studied based on this tiny calcareous nannofossils.

The Rizu section is located $70 \mathrm{~km}$ southwest of Tabas city ( $\left.33^{\circ} 08^{\prime} 35.53^{\prime \prime} \mathrm{N}, 56^{\circ} 10^{\prime} 08.27^{\prime \prime} \mathrm{E}\right)$. The Kamar-e-Mehdi section is located $35 \mathrm{~km}$ southwest of Tabas city $\left(33^{\circ} 05^{\prime} 14^{\prime \prime}\right.$ N, 56 28'19" E) (Figure 2). These two sections can be reached through the asphalt road of Tabas-Yazd. The distance between the two sections is approximately $35 \mathrm{~km}$.

Most of the biostratigraphic studies performed on this formation are mainly based on the ammonite fauna and indicate an early Bathonian-mid Callovian age (SeyedEmammi et al., 1991, 2002, 2004, Seyed-Emammi, 1998; Wilmson et al., 2009). In addition, the study of corals in the Baghamshah formation suggests a mid Bathonianlate Bathonian age (Pandey \& Fürsich, 2003). The latest biostratigraphy studies performed on this formation based on ammonite fauna and non-index genus of calcareous nannofossils such as Cyclogelosphera and Watznaueria, showed an early Callovian age too (Kallanxhii et al., 2016). According to the mentioned studies, the age of the Baghamshah Formation has been reported as Jurassic. Therefore, since calcareous nannofossils are useful tools to determine the accurate age of deposits, and the Baghamshah Formation lack such studies, the investigation of calcareous nannofossils of this formation is needed. Nannofossils studies in Baghamshah Formation are relatively new. Recently some calcareous nannofossils were reported from this formation by Bordbar et al. (2018), Khodashenas et al. (2018) and Behdani et al. (2019a, b).

Hence, the main purposes of this research are reviewing this formation based on calcareous nannofossils for determination of existing zones and comparing them to global standards and age. In this paper, the Baghamshah Formation has been investigated based on calcareous nannofossils in the Rizu and Kamar-e-Mehdi (southwest Tabas) sections.

\section{Lithostratigraphy of the Baghamshah Formation in the studied sections}

The thickness of the Baghamshah Formation in the Rizu section is $270 \mathrm{~m}$. Its lower boundary is conformable with the Parvadeh Formation and it is overlaid conformably with the Pectinid limestones of the Kamar-e-Mehdi Formation. The Baghamshah Formation analyzed in this section mainly consists of alternating green to grey marl-shale with intercalation of thinbedded calcareous sandstones and brown thin-bedded lomashel limestones (Figures 3, 4). The thickness of the Baghamshah Formation in Kamr-e-Mehdi section is $236 \mathrm{~m}$. It is underlaid with the grey pisoidal limestones of the Parvadeh Formation. Its upper boundary is the Kamar-e-Mehdi Formation, which has not been seen in this section due to erosion. The Baghamshah

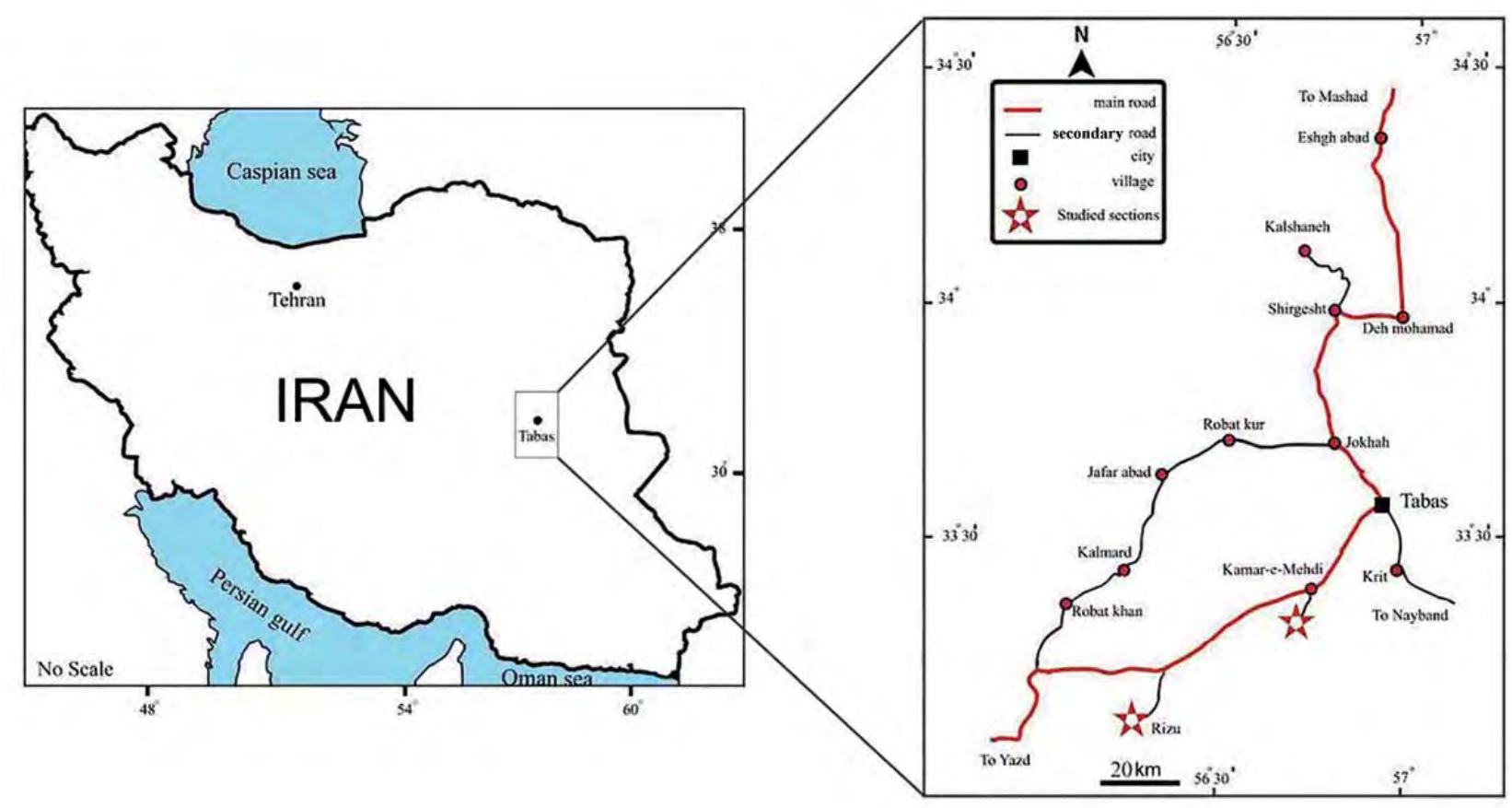

Figure 2. Location map of the studied sections in the southwest Tabas, east of Central Iran. 

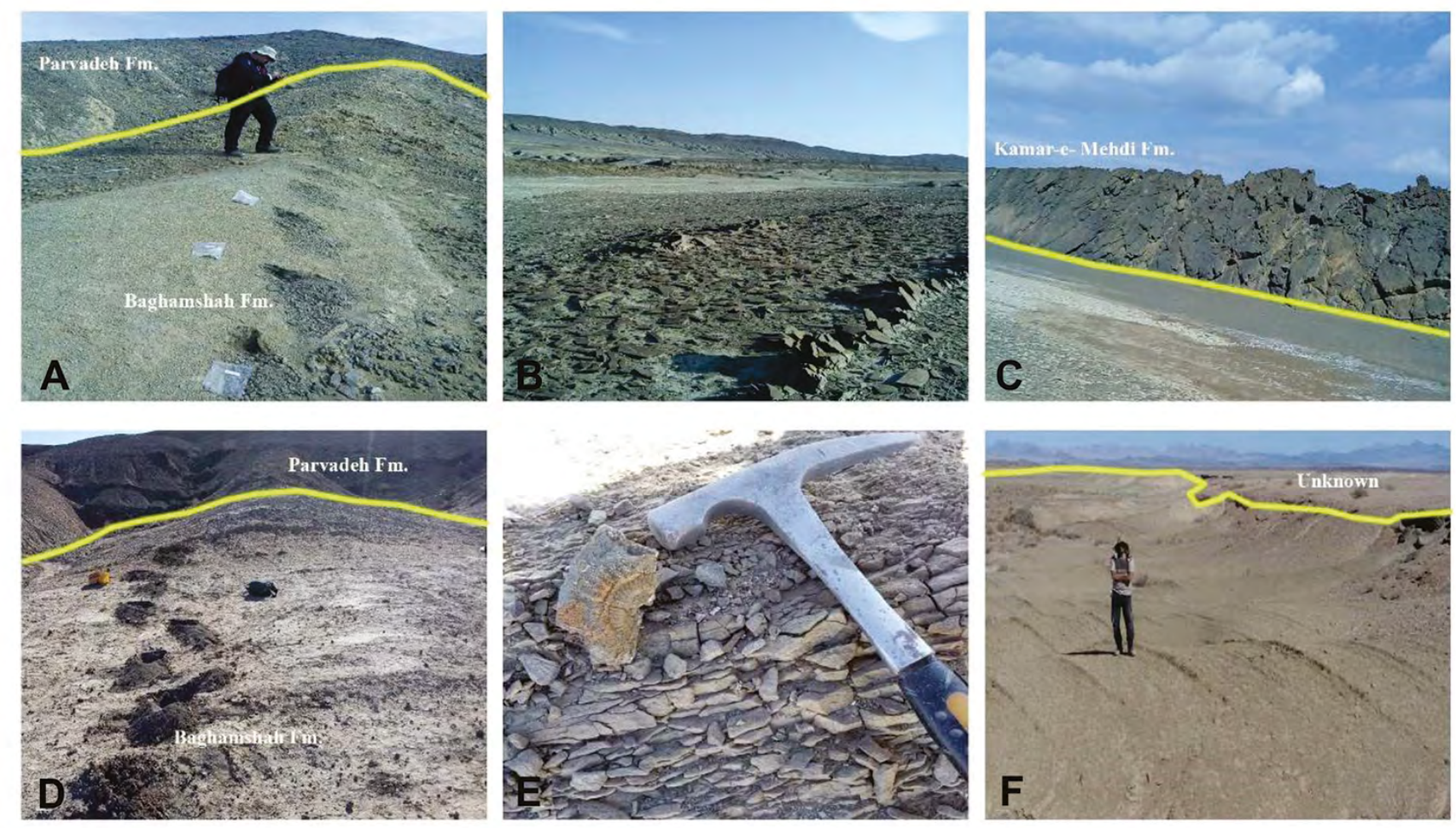

Figure 3. A, lower boundary of the Baghamshah Formation with the Parvadeh Formation. B, marl-shales with intercalation of calcareous sandstones. C, upper boundary of the Baghamshah Formation with the Kamar-e-Mehdi Formation. D, lower boundary of the Baghamshah Formation with the Parvadeh Formation. E, fragments of ammonites in gypsiferous marly shale. F, upper boundary of Baghamshah Formation is unknown (A-C belong to Rizu section; D-F, Kamar-e-Mehdi section; All site views are southwest).

Formation in this section is composed of light green gypsiferous marly shales containing fragments of ammonites, belemnites, Pentacrinus, green marl with intercalation of brown limestone, green gypsiferous marl with intercalation of siltstones containing fragments of ammonites, grey marly shales, and an alternation of green marl-shales with intercalation of thinbedded siltstones (Figures 3, 5).

\section{MATERIAL AND METHODS}

In order to study the calcareous nannofossils biostratigraphy of Baghamshah, a total of 44 samples from intervals of green marl-shales with thin-bedded sandstones (RB1-RB25), sandstones with intercalated limestones (RB26), green shales (RB27-RB38) and shale-fine sandstones (RB40-RB42) with intercalated limestones (RB39, RB43, RB44), were collected from the Rizu section; and 58 rock samples from the intervals of green gypsiferous marly shales (MB1-6), green marls with brown thin-bedded limestones (MB7-MB24), green-gray gypsum marls with intercalated siltstones (MB25-MB46), gray marly shales (MB47-MB50) and alternating green marlshales with intercalations of thin-bedded siltstones (MB51MB58) from the Kamar-e-Mehdi section were collected too. Samples were prepared by the smear-slide method (Bown \& Young, 1998), and analyzed under an Olympus BX51 light microscope with 100x objective lens and emersion oil. For the identification of nannofossil species, the reports provided by Perch-Nielsen (1985) and Bown (1998) were used, and their images are shown in Figures 6-9. In addition, the Roth (1973) pattern with changes was used to determine the degree of preservation of the calcareous nannofossils in this study. According to this pattern, the calcareous nannofossils were divided into good, moderate, and poorly preserved, taking into account their resistance to dissolution, corrosion, and diagenesis. The study of the degree of preservation of the calcareous nannofossils in both Rizu and Kamar-e- Mehdi sections showed that in the Rizu section the degree of preservation of calcareous nannofossils was poorly moderate, and in the Kamar-e-Mehdi section moderate.

\section{RESULTS AND DISCUSSION}

\section{Calcareous nannofossils}

In the studied samples, 52 species belonging to 24 genera in the Rizu section and 45 species belonging to 23 genera in the Kamar-e-Mehdi section were found (Figures $4,5)$. The preservation in the Kamar-e-Mehdi section was better than in the Rizu section. Lithraphidites carnniolensis, Nannoconus stainmanii, Nannoconus kamptneri, Watznaueria barnesae, and Conusphera mexicana were seen across the two sections. Nannoconus stainmanii, Nannoconus quadratus, Nannoconus globulus, Nannoconus dolomiticus, Kokia borealis and Diazomatolithus lehmanii are present at the beginning of both sections, and species such as Nannoconus 


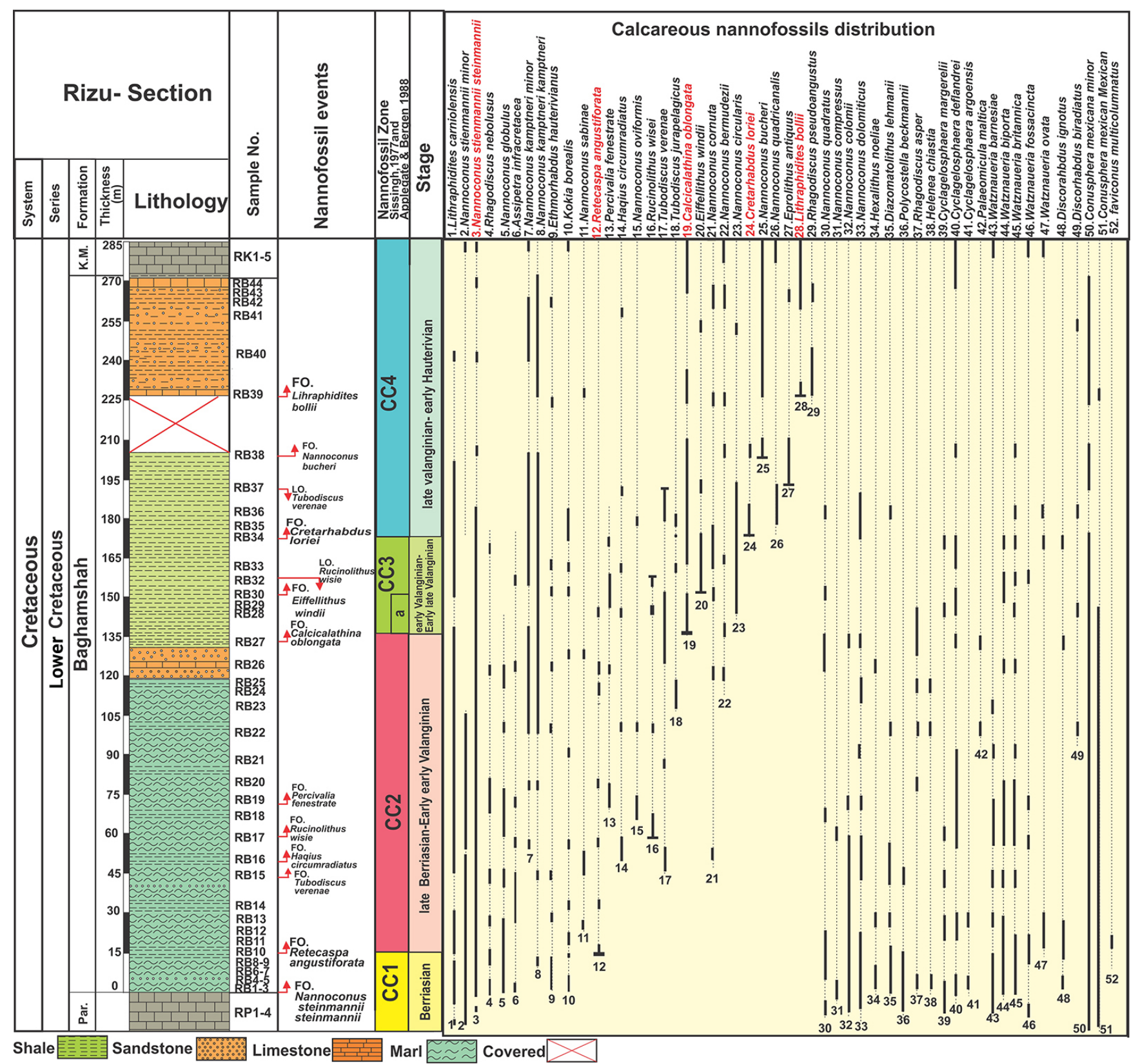

Figure 4. Lithostratigraphic column, distribution table of calcareous nannofossils and biozonation of Baghamshah Formation in the Rizu section.

cicularis, Nannoconus bucheri, Nannoconus quadricanalis, Calcicalatina oblongata and Lithraphidites bollii were more abundant in the upper parts of both sections.

\section{Biostratigraphy}

Biozonations of the calcareous nannofossils of the Lower Cretaceous of the Tethys were presented by Manivit (1971), Thierstein (1971, 1973), Sissingh (1977), Roth (1978, 1983), Perch-Nielsen (1979), Applegate \& Bergen (1988), and Bralower et al. (1989, 1995) (Figure 10). In this study the calcareous nannofossil biostratigraphy formerly established by Sissingh (1977), that Applegate \& Bergen (1988) modified and illustrated, was refined, based on the first and last occurrences (FO and LO) of index species.
According to marker species of nannofossils, five biozones were recognized, from base to top $\mathrm{CC} 1, \mathrm{CC} 2, \mathrm{CC} 3$ and $\mathrm{CC} 4$ biozones in both Rizu and Kamar-e-Mehdi sections, and the CC5 biozone was only recognized in the Kamar-e-Mehdi section (Figures 4-5). The identified nannofossils biozones were characterized as follows below.

\section{Nannoconus steinmannii Zone (CC1)}

This biozone was proposed by Worsley (1971), revised by Thierstein (1971) and Sissingh (1977), and defined from the first occurrence of Nannoconus steinmannii steinmannii to the first occurrence of Cretarhabdus crenulatus. The time interval of this biozone is early Berriasian (Applegate \& Bergen, 1988). 


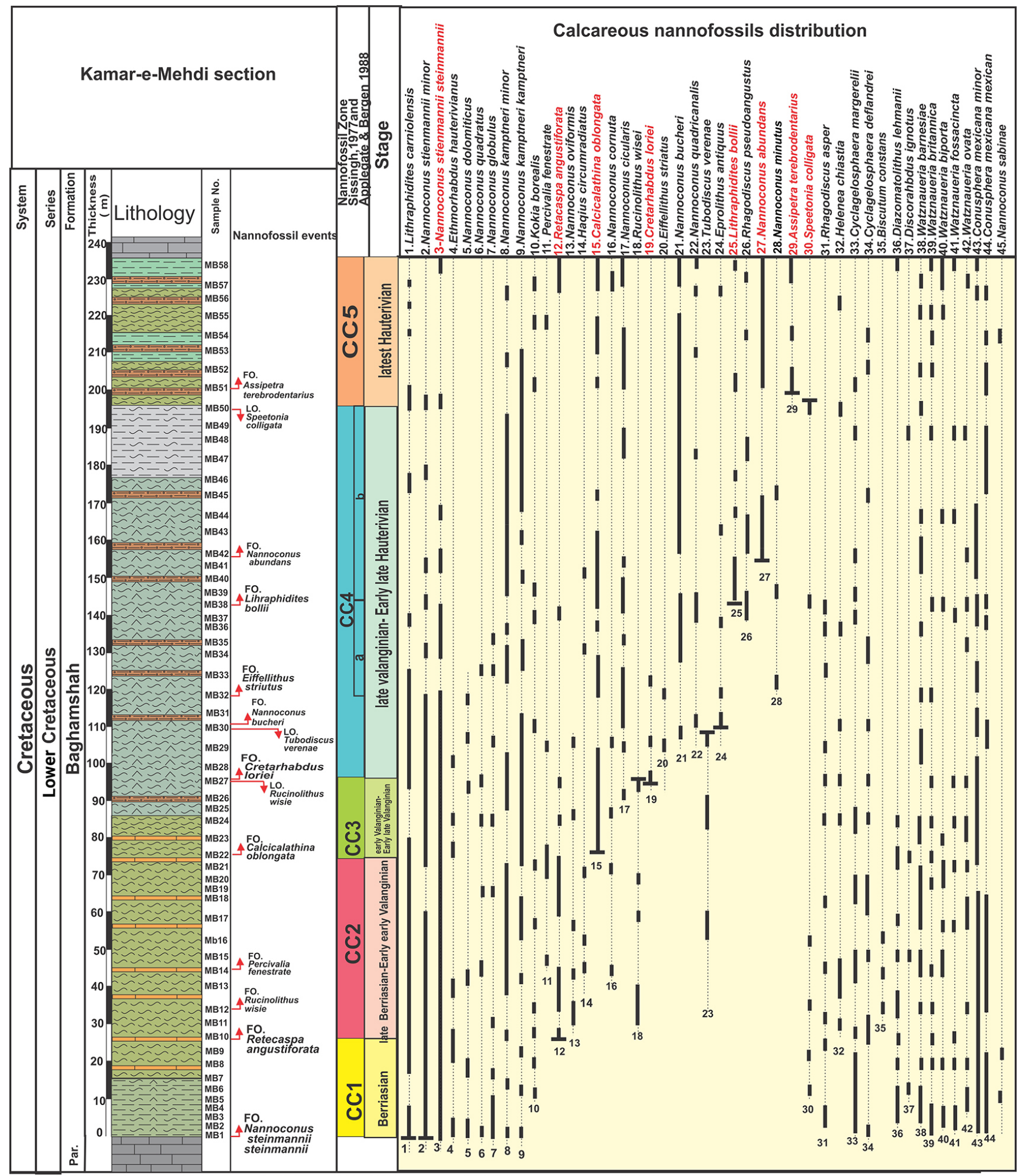

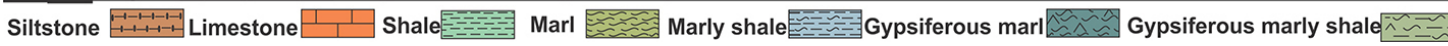

Figure 5. Lithostratigraphic column, distribution of calcareous nannofossils and biozonation of the Baghamshah Formation in the Kamar-e-Mehdi section. 

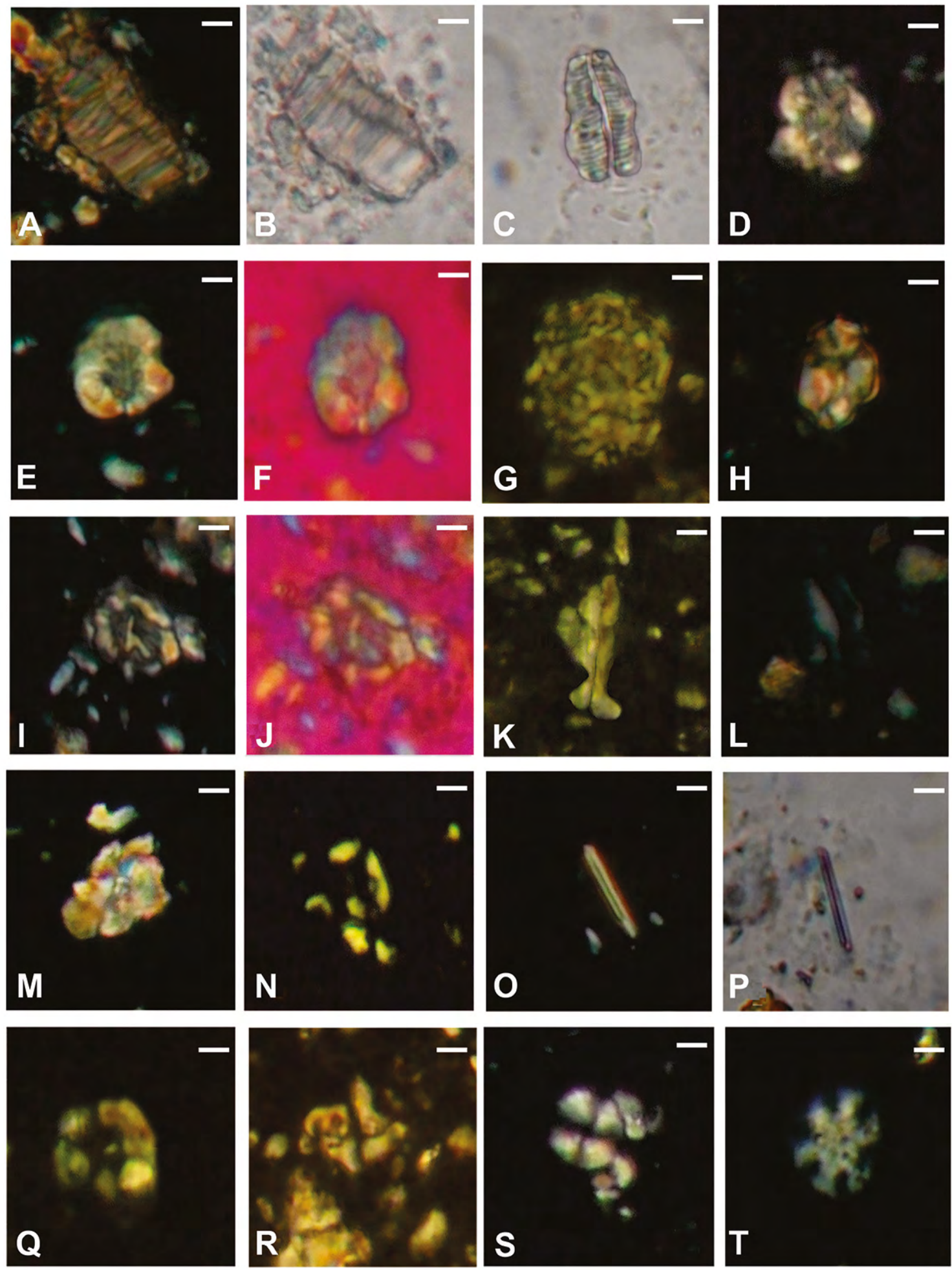

Figure 6. Calcareous nannofossils from the Rizu section. XPL, cross polarized light, PPL, plane polarized light, GP, gypsum plate; RB, Rizu section. A, Nannoconus steinmannii steinmannii; RB10, XPL. B-C, Nannoconus steinmannii steinmannii; RB10, RB17, PPL. D-F, Retecapsa angustiforata; RB14, RB26, XPL and GP. G-H, Calcicalathina oblongata; RB30, RB34, XPL. I-J, Cretarhabdus loriei; RB34, XPL and GP. K, Lithraphidites bollii; RB44, XPL. L, Rhagodiscus pseudoangustus; RB39, XPL. M, Rucinolithus wisei; RB17, XPL. N, Eiffellithus windii; RB34, XPL. O-P, Lithraphidites carniolensis; RB8, XPL and PPL. Q, Eprolithus antiquus; RB37, XPL. R, Palaeomicula maltica; RB28, XPL. S, Discorhabdus ignotus; RB9, XPL. T, Discorhabdus biradiatus; RB41, XPL. Scale bars $=2 \mu \mathrm{m}$. 
Regarding the presence of Nannoconus steinmannii steinmannii in the first sample of both Rizu and Kemere-Mehdi sections, the base of Baghmeshah Formation is lower Berriasian. Also, due to the absence of Cretarhbdus crenulatus for determining the upper boundary of this biozone, it was documented by Retecapsa angustiforata according to Thierstein (1976) and Applegate \& Bergen (1988). This species was firstly present in the Rizu section $15 \mathrm{~m}$ from the base, and in the Kamar-e-Mehdi section, at 27 $\mathrm{m}$. The thickness of this biozone is $15 \mathrm{~m}$ in the Rizu section and consists of green marls and shales with intercalation of brown sandstones. The thickness of this biozone in the Kamar-e-Mehdi section is $27 \mathrm{~m}$, it dominantly consists of gypsiferous marly shales. Conusphaera mexicana minor, Conusphera mexicana mexicana, Watznaueria barnesiae, Watznaueria fossacincta, Lithraphidites carniolensis, Polycostella beckmanii, Cyclagelosphaera margerelii, Diazomatolithus lehmanii, Kokia borealis, Percivalia fenestratae, Haqius circumradiatus, Rucinolithus wisie, Tubodiscus verenae, Nannoconus steinmannii steinmannii, Nannoconus steinmannii minor, Nannoconus quadratus, Nannoconus dolomiticus, and Nannoconus globulus are important components of the nannofossil assemblages throughout this zone.

It should be mentioned that due to the presence of Nannoconus steinmannii steinmannii in the underlying deposits (Parvadeh Formation) in the Rizu section (Bordbar et al., 2018), the CC1 is started on Parvadeh Formation before the occurrence of the Baghamshah Formation (Figure 4). As we could not take samples from the Parvadeh Formation in Kamar-e-Mehdi section (Figure 5), we could not determine where the $\mathrm{CC} 1$ starts in this section.

\section{Cretarhbdus crenulatus Zone (CC2)}

This biozone was presented by Sissingh (1977) and defined from the first occurrence of Cretarhbdus crenulatus to the first occurrence of Calcicalathina oblongata. The time interval of this biozone is late Berriasian and early Valanginian according to Perch-Nielsen (1985), while according to Ogg et al. (2012) the age of this biozone is early-late Berriasian.

As mentioned before, the lower boundary of this biozone was determined by the presence of Retecapsa angustiforata in both sections; the upper boundary was located in the Rizu section $134 \mathrm{~m}$ from the base, and in the Kamar-e-Mehdi section $74 \mathrm{~m}$ from the base, considering the first occurrence of Calcicalathina oblongata. The thickness of this biozone in the Rizu section comprises $119 \mathrm{~m}$ and is mainly composed of marl-shales, green shales with intercalations of lomashel limestones and brown sandstones. The thickness of this biozone is $47 \mathrm{~m}$ in Kamar-e-Mehdi section, and consists of green marls with intercalations of limestones. In the present study, the first occurrences of Percivalia fenestratae, Haqius circumradiatus, Rucinolithus wisie, Tubodiscus verenae are recorded in this zone. In the Rizu section, the first occurrence of Tobodiscus verenae ( $45 \mathrm{~m}$ from the base) is earlier than that of Rucinolithus wisie, while in the Kamar-e-Mehdi section the first occurrence of $R$. wisie is at $34 \mathrm{~m}$ from the base. Bralower et al. $(1989,1995)$ divided this zone into two subzones, NK2a and NK2b, based on the first occurrence of Percivalia fenestratae. This species is recorded in the Rizu section at $73 \mathrm{~m}$ from the base, and in the Kamr-eMehdi section at $45 \mathrm{~m}$. Conusphaera mexicana minor, Conusphera mexicana mexicana, Watznaueria barnesiae, Watznaueria fossacincta, Watznaueria britanica, Watznueria biporta, Watznaueria ovata, Lithraphidites carniolensis, Diazomatolithus lehmanii, Cyclagelosphaera margerelii, Cyclagelosphaera deflandrei, Percivalia fenestratae, Haqius circumradiatus, Rucinolithus wisie, Tubodiscus verenae, Ethmorhabdus hauterivianus, Nannoconus steinmannii steinmannii, Nannoconus steinmannii minor, Nannoconus kamptneri minor, Nannoconus kamptneri kamptneri, Nannoconus dolomiticus, and Nannoconus globulus are important components of the nannofossil assemblages throughout this zone.

\section{Calcicalathina oblongata Zone (CC3)}

This biozone was presented by Thierstein (1971) and revised by Sissingh (1977) and defined from the first occurrence of Calcicalathina oblongata to the first occurrence of Cretarhabdus loriei. The time interval of this biozone is the early Valanginian-early late Valanginian (Perch-Nielsen, 1985; Applegate \& Bergen, 1988).

The lower boundary of this biozone, based on the first occurrence of Calcicalathina oblongata, is considered in the Rizu section at $134 \mathrm{~m}$ from base and in Kamar-eMehdi section at $74 \mathrm{~m}$ from the base. The upper boundary of this biozone was determined with the first occurrence of Cretarhabdus loriei at $170 \mathrm{~m}$ from the base in the Rizu section, and at $95 \mathrm{~m}$ from the base in the Kamar-e-Mehdi section. The thickness of this biozone in the Rizu section is $36 \mathrm{~m}$ and dominantly consists of green shale. In the Kamar-eMehdi section, this biozone is $21 \mathrm{~m}$ thick and mainly consists of gypsiferous marls with intercalations of siltstones. In the Rizu section, the first occurrence of Eiffellithus windii is identified at $150 \mathrm{~m}$ from the base. According to Applegate \& Bergen (1988) the CC3a subzone is represented from the first appearance of Calcicalathina oblongata to the first appearance of Eiffellithus windi. This subzone is recorded only in the Rizu section. According to Bralower et al. (1989, 1995), this biozone was divided into two subzones, NK3a and $\mathrm{NK} 3 \mathrm{~b}$, based on the last occurrence of Rucinolithus wisie. The last occurrence of this species was determined at $158 \mathrm{~m}$ from the base in the Rizu section and at $95 \mathrm{~m}$ in the Kamare-Mehdi section. Conusphaera mexicana minor, Conusphera mexicana mexicana, Lithraphidites carniolensis, Watznaueria barnesiae, Watznaueria fossacincta, Watznaueria britanica, Watznueria biporta, Watznaueria ovata, Cyclagelosphaera deflandrei, Nannoconus steinmannii steinmannii, Nannoconus steinmannii minor, Nannoconus kamptneri minor, Nannoconus kamptneri kamptneri, Nannoconus cornuta, and Nannoconus circularis are important components of the nannofossil assemblages throughout this zone. 

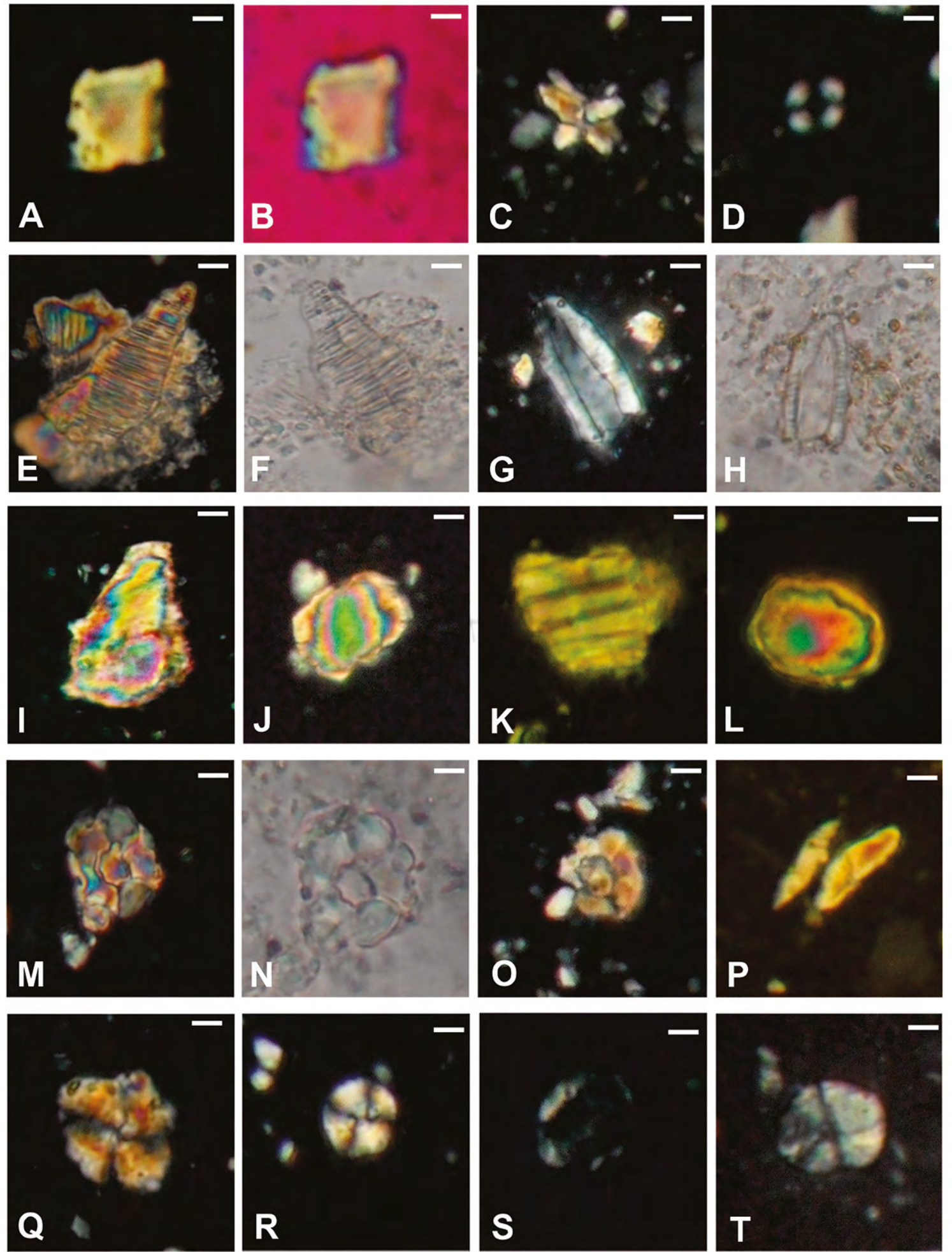

Figure 7. Calcareous nannofossils from the Rizu section. XPL, cross polarized light; PPL, plane polarized light, GP, gypsum plate; RB, Rizu section. A-B, Nannoconus quadratus; RB36, XPL and GP. C, Kokia borealis; RB8, XPL. D, Diazomatolithus lehmanii; RB10, XPL. E-F, Nannoconus bermudezii; RB39, XPL and PPL. G-I, Nannoconus kamptneri kamptneri; RB26, RB23, XPL and PPL. J, Nannoconus globulus; RB2, XPL. K, Nannoconus sabinae, RB16, XPL. L, Nannoconus circularis; RB28, XPL. M-N, Nannoconus quadricanalis; RB36, XPL and PPL. O, Nannoconus cornuta; RB26, XPL. P, Nannoconus dolomiticus; RB24, XPL. Q, Cyclagelosphaera deflandrei; RB34, XPL. R, Cyclagelosphaera margerelii; RB13, XPL. S, Ethmorhabdus hauterivianus; RB30, XPL. T, Haqius circumradiatus; RB22, XPL. Scale bars $=2 \mu \mathrm{m}$. 

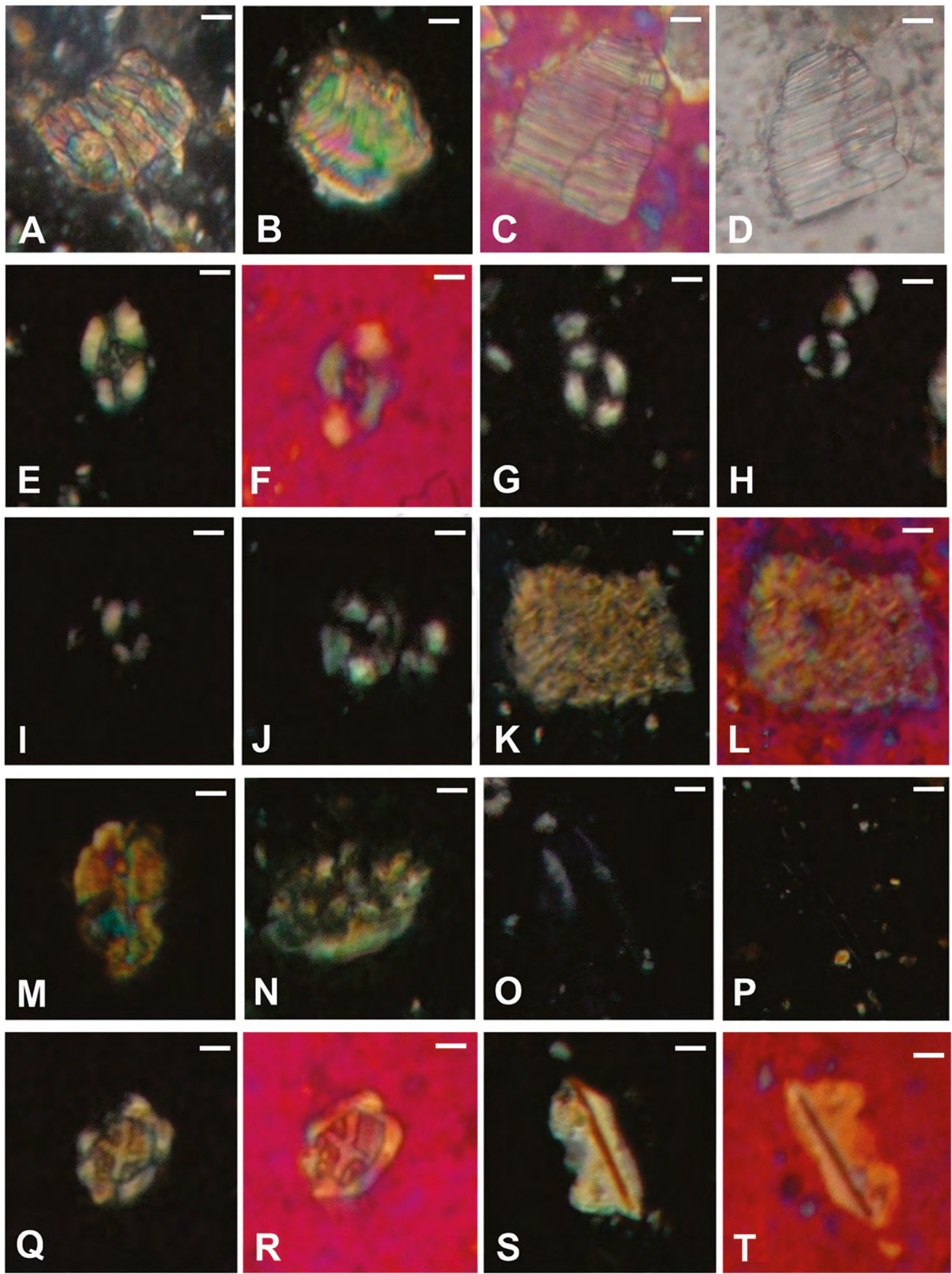

Figure 8. Calcareous nannofossils from the Kamar-e-Mehdi section. XPL, cross polarized light; PPL; plane polarized light; GP, gypsum plate; MB, Kamar-eMehdi section. A-B, Nannoconus steinmannii steinmannii; MB3, MB12, XPL. C-D, Nannoconus steinmannii steinmannii; MB4, GP and PPL. E-F, Retecapsa angustiforata; MB12, XPL and GP. G, Watznaueria ovata; MB8, XPL. H-I, Diazomatolithus lehmanii; MB8, MB21, XPL. J, Biscutum constans; MB16, XPL. K-L, Nannoconus oviformis; MB29, XPL and GP. M-N, Calcicalathina oblongata; MB27, MB36, XPL. O, Rhagodiscus pseudoangustus; MB37, XPL. P, Lithraphidites carniolensis; MB27, XPL. Q-R, Cretarhabdus loriei; MB27, XPL and GP. S-T, Lithraphidites bollii; MB38, XPL and GP. Scale bars $=2 \mu \mathrm{m}$. 

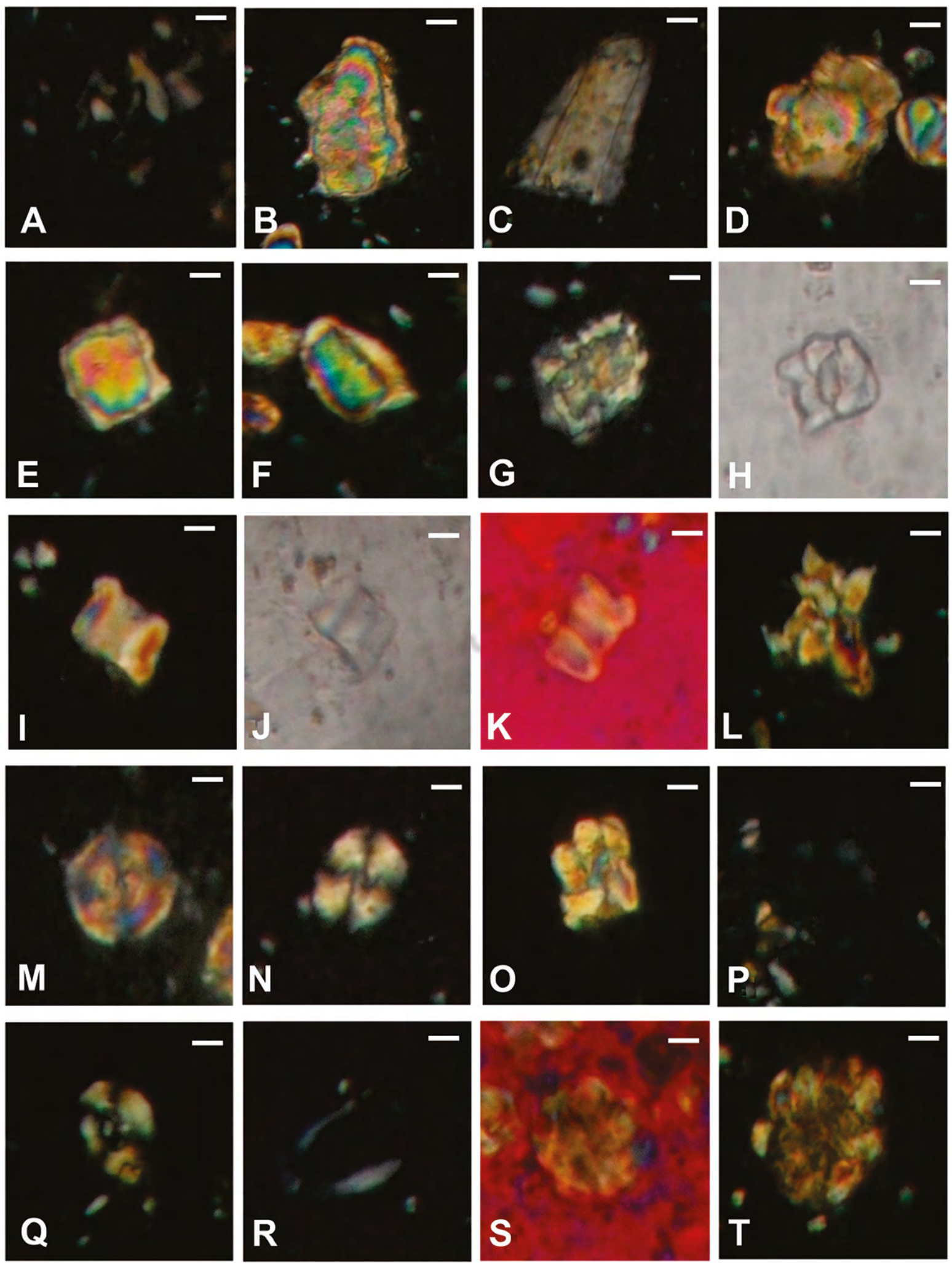

Figure 9. Calcareous nannofossils from the Kamar-e-Mehdi section. XPL, cross polarized light, PPL, plane polarized light, GP, gypsum plate, MB, Kamare-Mehdi section. A, Eiffellithus striatus; MB58, XPL. B-C, Nannoconus kamptneri kamptneri; MB27, MB54, XPL. D, Nannoconus globulus; MB3, XPL. E, Nannoconus circularis; MB26, XPL. F, Nannoconus bucheri; MB41, XPL. G, Rhagodiscus asper; RB18, XPL. H, Nannoconus cornuta; MB20, XPL. I-K, Nannoconus abundans; MB44, XPL, PPL and GP. L, Kokia borealis; MB51, XPL. M, Cyclagelosphaera deflandrei; MB54, XPL. N, Cyclagelosphaera margerelii; MB10, XPL. O, Rucinolithus wisei; RB20, XPL. P, Speetonia colligate; MB38, XPL. Q, Helenea chiastia; MB24, XPL. R, Ethmorhabdus hauterivianus; MB32, XPL. S-T, Assipetra terebrodentarius; MB52, GP; MB54, XPL. Scale bars $=2 \mu \mathrm{m}$. 


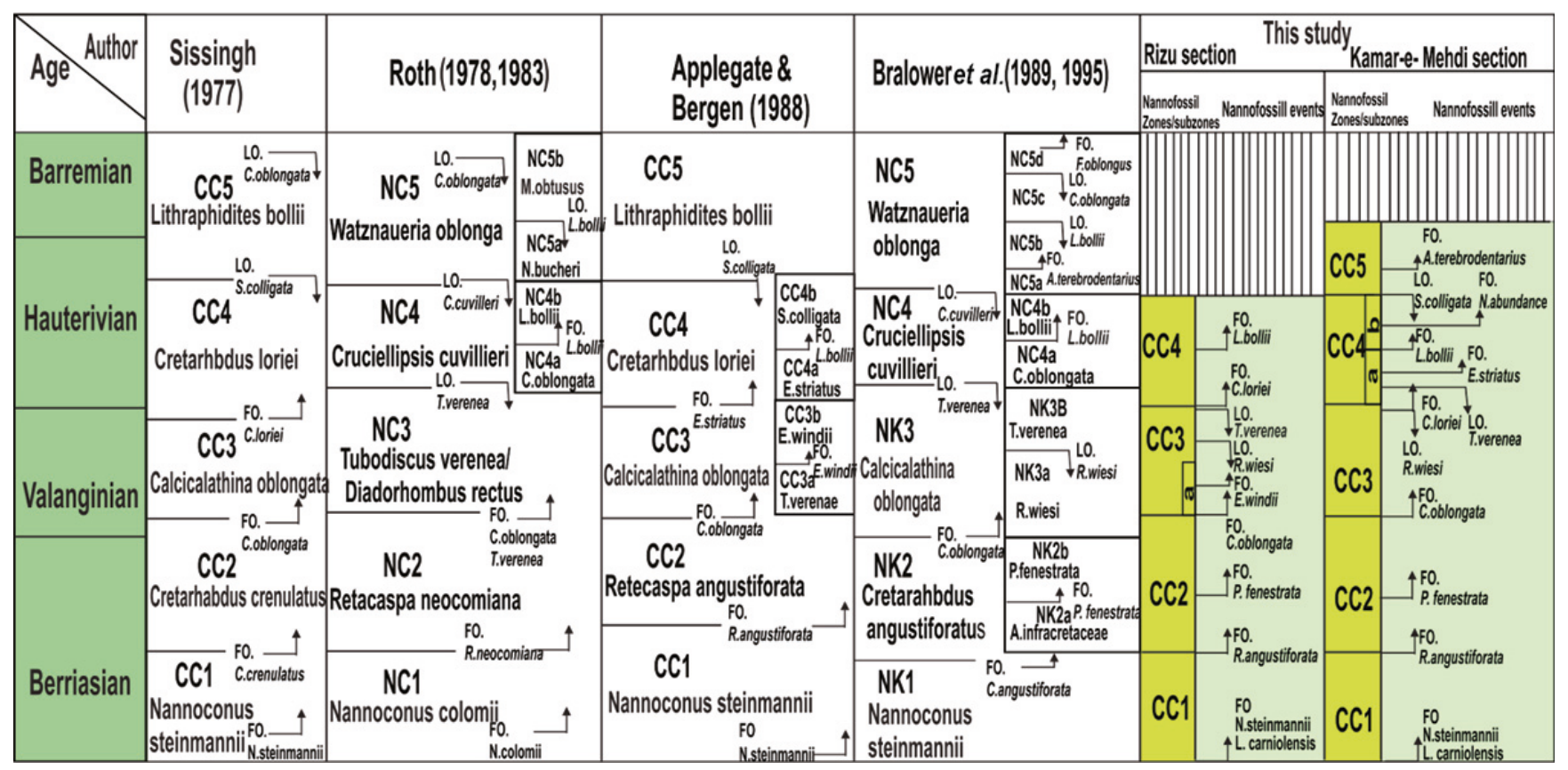

Figure 10. Nannofossil zones and events identified in the Baghamshah formation in the Rizu and Kamar-e-Mehdi sections, and its comparison with the calcareous nannofossil zonation schemes for the Lower Cretaceous (Berriasian-Barremian) in the Tethys presented by Sissingh (1977), Roth (1978, 1983), Applegate \& Bergen (1988) and Bralower et al. (1989, 1995).

\section{Cretarhabdus loriei Zone (CC4)}

This biozone was presented by Sissingh (1977) and defined from the first occurrence of Cretarhabdus loriei to the last occurrence of Speetonia colligata. The time interval of this biozone is the late Valanginian-early late Hauterivian according to Perch-Nielsen (1985), while Applegate \& Bergen (1988) claimed that the age of this biozone is early Hauterivian-early late Hauterivian.

As stated before, the lower boundary of this biozone was determined in the Rizu section by the first occurrence of Cretarhabdus loriei at $170 \mathrm{~m}$ from the base and in the Kamar-e-Mehdi section at $95 \mathrm{~m}$ from the base. Regarding the absence of Speetonia colligata in the Rizu section, the upper boundary of this biozone, according to Thierstein (1976), was determined on the basis of the presence of Lithraphidites bollii. This species is of early Hauterivian age.

The first occurrence of Lithraphidites bollii in the Rizu section is at $228 \mathrm{~m}$, but in the Kamar-e-Mehdi section, this boundary was determined based on the last occurrence of Speetonia colligata. This species is recorded at a thickness of $195 \mathrm{~m}$. According to Applegate \& Bergen (1988), this biozone is divided into two subzones, $\mathrm{CC} 4 \mathrm{a}$ and $\mathrm{CC} 4 \mathrm{~b}$, based on first occurrence of Lithraphidites bollii. Because of the lack of Eiffellithus striatus and Speetonia colligata in the Rizu section, the lower and upper boundaries of this biozone are not detectable, but in the Kamar-e-Mehdi section, due to the existence of both species above CC4a and $\mathrm{CC} 4 \mathrm{~b}$, it can be determined. The species Eiffellithus striatus is recorded at $118 \mathrm{~m}$ from the base. The first occurrence of Lithraphidites bollii has been recorded at $142 \mathrm{~m}$ from the base. According to Taylor (1982) the first presence of Nannoconus abundanse suggest an early late Hauterivian age.
This species appears at $158 \mathrm{~m}$ from the base. The thickness of the CC4 biozone is $100 \mathrm{~m}$ in the Rizu section and consists of shales with brown fine-grained sandstones interbedded. In the Kamar-e-Mehdi section, the thickness of this biozone is $100 \mathrm{~m}$, and it is mainly composed of gypsiferous marls with intercalation of siltstones. In addition, in this section the thickness of the $\mathrm{CC} 4 \mathrm{a}$ and $\mathrm{CC} 4 \mathrm{~b}$ subzones was 47 and 53 $\mathrm{m}$, respectively. Conusphaera mexicana minor, Conusphera mexicana mexicana, Watznaueria barnesiae, Watznaueria fossacincta, Watznaueria britanica, Watznueria biporta, Watznaueria ovata, Cyclagelosphaera deflandrei, Kokia borealis, Calcicalathina oblongata, Eprolithus antiquus, Nannoconus kamptneri minor, Nannoconus kamptneri kamptneri, Nannoconus circularis, Nannoconus bucheri, Nannoconus quadricanalis and Rhagodiscus pseudoangstus are important components of the nannofossil assemblages throughout this zone.

\section{Lithraphidites bollii Zone (CC5)}

This biozone was presented by Thierstein (1971) and revised by Sissingh (1977). It extends from the last occurrence of Speetonia colligata to the latest occurrence of Calcicalathina oblongata. The time interval is late Hauterivian-early Barremian (Perch-Nielsen, 1985; Applegate \& Bergen, 1988). This biozone has been identified only in the Kamare-Mehdi section. As mentioned above, the lower boundary of this zone was determined by the presence of Speetonia colligata at $195 \mathrm{~m}$ from the base. Due to the continued presence of Calcicalathina oblongata at the end of this section, the upper boundary was not determined. However, according to Bralower et al. $(1989,1985)$, the first presence of Assipetra terbrodentarius indicates late Hauterivian age, 
and this species is recognized at $200 \mathrm{~m}$ from the base. The thickness of this biozone is $41 \mathrm{~m}$ and includes gypsiferous marls with intercalation of brown siltstones, grey marly shales, and alternation of green marl-shales with interbedded siltstones. Conusphaera mexicana minor, Conusphera mexicana mexicana, Calcicalathina oblongata, Watznaueria barnesiae, Watznaueria fossacincta, Watznaueria britanica, Watznueria biporta, Watznaueria ovata, Cyclagelosphaera deflandrei, Rhagodiscus pseudoangstus, Eprolithus antiquus, Nannoconus kamptneri minor, Nannoconus kamptneri kamptneri, Nannoconus circularis, Nannoconus bucheri, Nannoconus quadricanalis, and Lithraphidites bollii are important components of the nannofossil assemblages throughout this zone.

In this study, the presence of Lithraphidites bollii and absence of Speetonia colligata in the last sample, indicates an early Hauterivian age for the top of the Baghamshah Formation in the Rizu section. In the Kamar-e-Mehdi section, the continued presence of Nannoconus abundans, indicating an early late Hauterivian age from the $158 \mathrm{~m}$, and Assipetra terbrodentarius with a late Hauterivian age from $200 \mathrm{~m}$ to the top of this section, indicate the age of the late Hauterivian for the upper parts of the Baghamshah Formation.

\section{CONCLUSIONS}

Investigations of calcareous nannofossils of Baghamshah Formation in the Rizu and Kamar-e-Mehdi sections, which are parts of the Tethys realm, led to identify 52 species belonging to 24 genera in the Rizu section, and 45 species belonging to 23 genera in the Kamar-e-Mehdi section. Previous studies on the Baghamshah Formation were mainly based on ammonites and other macrofossil groups, and the present study is based on calcareous nannofossils on this formation for the first time. According to the first appearance of Nannoconus steinmannii stainmannii and Lithraphidites carniolensis in the first samples from both sections, the age of the basis of the Baghamshah Formation in both sections is equivalent to the CC1 biozone of Sissingh (1977), with Berriasian age. $\mathrm{CC} 1, \mathrm{CC} 2, \mathrm{CC} 3$ and $\mathrm{CC} 4$ biozones, based on the biozonation scheme of Sissingh (1977), were recorded in both sections. The CC5 biozone was found only in the upper part of the Kamar-e-Mehdi section. Therefore, a Berriasianearly Hauterivian age is suggested for the Baghamshah Formation in the Rizu section, and a Berriasian-late Hauterivian age for this formation in the Kamar-e-Mehdi section. Preservation of the calcareous nannofossils is poor to moderate in the Rizu section and moderate in the Kamare-Mehdi section, which could be related to the lithology in the first section.

The lack of the CC5 biozone in the Rizu section could be related to the sandy lithology, that may represent the shallowest depth of the Kamar-e-Mehdi section. As these are the first studies on calcareous nannofossils of the Baghamshah Formation, for a best interpretation of the basin we need more data and to examine different sections of the Baghamshah Formation in Tabas and Lut Block in the future.

\section{REFERENCES}

Aghanabati, S.A. 1977. Étude géologique de la région de Kalmard (W. Tabas). Geological Survey of Iran, 35:1-230.

Applegate, J.L. \& Bergen, J.A. 1988. Cretaceous calcareous nannofossil biostratigraphy of sediments recovered from the Galicia margin, ODP Leg 103. In: G. Boillot et al. (eds.) Proceedings of the Ocean Drilling Program, Scientific Results, Ocean Drilling Project, p. 293-348.

Behdani, E.; Hadavi, F. \& Notghi-moghaddam, M. 2019a. Nannostratigraphy of Baghamshah Formation in Esfandiar section (Tabas block). In: CONFERENCE OF PALEONTOLOGY SOCIETY OF IRAN, 12, 2019. Actas, p. 35-39.

Behdani, E.; Hadavi, F.; Notghi-moghaddam, M. \& Khazaie, A.R. 2019b. Biostratigraphy of the Baghamshah Formation based on calcareous nannofossils in the Deheshk section (North of Lut Block). Sedimentary Facies, 12:23-34.

Bordbar, A.; Hadavi, F.; Notghi-moghaddam, M. \& Ghaderi, A. 2018. Biostratigraphy of the boundary between Parvadeh and Baghamshah formations based on calcareous nannofossils in the western margin of Tabs (Rizu section). In: SYMPOSIUM OF GEOLOGICAL SOCIETY OF IRAN, 21; GEOLOGICAL NATIONAL CONFERANCE OF PAYAME NOOR UNIVERSITY, 11, 2018. Actas, p. 62-68.

Bown, P.R. 1998. Calcareous nannofossil biostratigraphy. London, Chapman and Hall, Kluwer Academic Publishers, 316 p.

Bown, P.R. \& Young, J.R. 1998. Techniques. In: P.R. Bown (ed.) Calcareous Nannofossil biostratigraphy, Chapman and Hall, p. 16-28.

Bralower, T.J.; Leckie, R.M.; Sliter, W.V. \& Thierstein, H.R. 1995. An integrated Cretaceous microfossil biostratigraphy. In: W.A. Berggren; D.V. Kent; M.P. Aubry \& J. Hardenbol (eds.) Geochronology time scales and global stratigraphic correlation, Society for Sedimentary Geology, p. 66-79.

Bralower, T.J.; Monechi, S. \& Thierstein, H.R. 1989. Calcareous nannofossil zonation of the Jurassic-Cretaceous boundary interval and correlation with the geomagnetic polarity timescale. Marine Micropaleontology, 14:153-235. doi:10.1016/03778398(89)90035-2

Kallanxhii, E.; Falahatgar, M.; Javidan, M.; Sarfi, M. \& Parvizi, T. 2016. Calcareous nannofossils and ammonites-based biostratigraphy of the Baghamshah Formation (Central Iran Basin, Iran). Studia Universitatea Babes-Bolyai Geologia, 60:29-42.

Khodashenas, N.; Hadavi, F. \& Notghi-moghaddam, M. 2018. Biostratigraphy of Baghamshah Formation based on calcareous nannofossils in Kharvan section, north Tabas. In: SYMPOSIUM OF GEOLOGICAL SOCIETY OF IRAN, 21; GEOLOGICAL NATIONAL CONFERENCE OF PAYAME NOOR UNIVERSITY, 11, 2018. Actas, p. 84-91.

Manivit, H. 1971. Nannofossiles calcaires du Crétacé francais (Aptien Maestrichtien). Essai de Biozonation appuyée sur les stratotypes. Université de Paris, Ph.D. Thesis, 187 p.

Ogg, J.G.; Hinnov, L.A. \& Huang, C. 2012. Cretaceous. In: F.M. Gradstein; J.G. Ogg,; M.D. Schmitz \& G.M. Ogg (eds.) The Geological Time Scale, Elsevier, vol. 7, p. 793-853.

Pandey, D.K. \& Fürsich, F.T. 2003. Jurassic corals of east central Iran. Beringeria, 32:3-138.

Perch-Nielsen, K. 1979. Calcareous nannofossils from the Cretaceous between the North Sea and the Mediterranean. In: J. Wiedmann (ed.) Aspekte der Kreide Europas, IUGS Series A, vol. 6, p. 223-272. 
Perch-Nielsen, K. 1985. Mesozoic Calcareous nannofossils In: H.M. Bolli; J.B. Saunders \& K. Perch-Nielsen (eds.) Plankton Stratigraphy, Cambridge University Press, p. 329-426.

Roth, P.H. 1973. Calcareous nannofossils Leg 17, Deep Sea Drilling Project. In: E.L. Winterer \& J.I. Ewing (eds.) Initial Reports of Deep-Sea Drilling Project, p. 695-795. doi:10.2973/dsdp. proc.17.123.1973

Roth, P.H. 1978. Cretaceous nannoplankton biostratigraphy and oceanography of the northwestern Atlantic Ocean. In: W.E. Benson et al. Initial Reports of Deep-Sea Drilling Project, p. 731-759. doi:10.2973/dsdp.proc.44.134.197

Roth, P.H. 1983. Jurassic and Lower Cretaceous nannofossils in the western north Atlantic (Site 534): biostratigraphy, preservation, and some observations on biogeography and paleoceanography. In: R.E. Sheridan \& F.M. Gradstein (eds.) Initial Reports of the Deep-Sea Drilling Project, p. 587-621. doi:10.2973/dsdp. proc.76.125.1983

Sengör, A.M.C. 1990. A new model for the late Palaeozoic-Mesozoic tectonic evolution of Iran and implications for Oman. In: A.H.F. Robertson; M.P. Searle \& A.C. Ries (eds.) The Geology and tectonics of the Oman region, Geological Society London Special Publication, vol. 49, p. 797-831.

Seyed-Emami, K. 1998. Jurassic and Cretaceous Ammonite faunas of Iran and their palaeo biogeographic significance. In: J. Widmann \& J. Kullmann (eds.) Cephalopods Present and Past, Schweizerbart, p. 599-606. doi:10.1144/GSL.SP.1992.049.01.49

Seyed-Emami, K. \& Alavi-Naini, M. 1990. Bajocian stage in lran. Memorie Descrittive della carta Geologica d'Italia, 40:215-222.

Seyed-Emami, K.; Fursich, F.T. \& Wilmsen, M. 2004. Documentation and significance of tectonic events in the northern Tabas Block (East Central Iran) during the Middle and late Jurassic. Rivista Italiana di Paleontologia e Stratigrafia, 110:163-171.

Seyed-Emami, K.; Schairer, G.; Aghanabati, A. \& Fazl, M. 1991. Ammoniten aus dem Bathon von Zentraliran (Tabas Naiband Region). Münchner Geowissenschaftliche Abhandlungen, A19:65-100
Seyed-Emami, K.; Schairer, G.; Fursich, F.T.; Willmsen, M. \& Majidifard, M.R. 2002. Reineckeiidae (Ammonoidea) from the Callovian (Middle Jurassic) of the Shotori Range (EastCentral Iran). Neues Jahrbuch fur Geologie und Palaontologie Monatshefte, 3:184-192. doi:10.1127/njgpm/2002/2002/184

Sissingh,W. 1977. Biostratigraphy of Cretaceous Calcareous nannoplankton. Geologie en Minjbouw, 56:37-65.

Taylor, R.J. 1982. Lower Cretaceous Calcareous nannofossils. In: A.R. Lord (ed.) A Stratigraphical index of Calcareous nannofossils, British Micropaleontology Society, p. 40-80.

Thierstein, H.R. 1971. Tentative Lower Cretaceous calcareous nannoplankton zonation. Eclogae Geologicae Helvetiae, 64:459-488.

Thierstein, H.R. 1973. Lower Cretaceous Calcareous Nannoplankton Biostratigraphy. Abhandlungen der Geologischen Bundesanstalt, 29:1-52.

Thierstein, H.R. 1976. Mesozoic Calcareous nannoplankton biostratigraphy of marine sediments. Marine Micropalaeontology, 1:325-362.

Wilmsen, M.; Fürsich, F.T.; Seyed-Emami, K. \& Majidifard, M.R. 2009. An overview of the stratigraphy and facies development of the Jurassic System on the Tabas Block, east-central Iran. Geological Society Special Publications, 312:323-343. doi: $10.1144 / \mathrm{SP} 312.15$

Worsley, T.R. 1971. Calcareous nannofossil zonation of Upper Jurassic and Lower Cretaceous sediments from the western Atlantic. In: PLANKTONIC CONFERENCE, 2, 1970. Proceedings, Rome, Edizioni Tecnoscienza, p. 1301-1321.

Received in 21 October, 2019; accepted in 31 January, 2021. 